\title{
Strategi Perencanaan Humas Media Sosial Radio OZ sebagai Upaya Transformasi Pendengar
}

\author{
Paramitha Wydaswari ${ }^{1}$, Susanne Dida ${ }^{2}$ dan FX Ari Agung Prastowo ${ }^{3}$ \\ ${ }^{1}$ PT. Duta Visual Nusantara Tivi Tujuh (TRANS7) \\ ${ }^{2,3}$ Universitas Padjadjaran
}

\begin{abstract}
ABSTRAK
Radio memiliki banyak manfaat, dengan menggunakan radio informasi dapat disampaikan dengan cepat ke masyarakat. Manfaat lainnya dari penggunaan radio adanya jangkaunnya yang luas dan menghibur karena memiliki keunggulan yakni suara. Persaingan radio saat ini sangat kuat, ditambah dengan kehadiran media sosial, dimana banyak masyarakat saat ini menggunakan media sosial untuk mencari dan menyebarkan informasi. Perkembangan media sosial juga dirasakan oleh Radio OZ. Pada masanya, Radio OZ sangat populer di kalangan remaja bahkan menjadi referensi gaya hidup remaja masa kini. Agar mampu bersaing di era yang kompetitif, Radio OZ menggunakan digital marketing untuk menjangkau pendengarnya. Oleh karena itu penelitian ini memiliki tujuan bagaimana menggunakan digital marketing dalam hal ini media sosial dengan perencanaan yang baik. Penelitian ini menggunakan metode deskriptif, untuk menggambarkan hasil penelitian secara mendalam. Adapun hasil penelitian menemukan enam langkah menggunakan media sosial dengan baik. Enam langkah tersebut adalah analisis situasi, penentuan tujuan, menentukan target, memilih strategi, taktik, dan yang terakhir adalah menyusun waktu penggunaan. Perkembangan digital marketing dalam wujud media sosial memberikan kemudahan bagi pengelola media penyiaran untuk mengkomunikasikan transformasi kepada pendengarnya. Namun demikian tetap harus memperhatikan langkah-langkah pemanfaatan media sosial di antaranya pemahaman situasi dengan mengedepankan penelitian sebagai radar akan kebutuhan pendengar.
\end{abstract}

Kata-kata Kunci: Strategi; perencanaan; media sosial; radio; transformasi

\section{Public Relations Strategic Planning of Social Media for Transformation Listener Radio $O Z$}

\section{ABSTRACT}

Radio has a lot of value, with the radio information can spread quickly to many people and the radio have a superiority that is audio. The other benefits of radio are easy to reach and entertain. Now Radio is very competitive, and Radio OZ feel the impact of competition. The competitor not only another radio but turn out of social media as a popular media, and many people use them. In the past, Radio OZ was very popular in the youngest segmentation and it becomes a reference as a lifestyle of youngest people. In order to remain able to compete Radio OZ using digital marketing to reach the new audience. This research has a purpose that is how to use social media with a good plan. The method of research is descriptive because with the descriptive method we can describe every step that plans by Radio OZ. We have six steps how to use social media to transform the listener and the steps are situation analysis, determine of goals, define the audiences, choosing the strategic and tactic, and the last is make a timeline. The development of digital marketing in the form of social media makes it easy for broadcast managers to communicate the transformation to their listeners. However, it must still pay attention to the steps to use social media, including understanding the situation by prioritizing research as a radar for the needs of listeners.

Keywords: Strategic; planning; social media; radio; transformation

Korespondensi: Paramitha Wydaswari, S.I.Kom. PT.Duta Visual Nusantara Tivi Tujuh (TRANS7) Menara Bank Mega, Lantai 22 JL. Kapten P. Tendean Kav.12-14A Jakarta 12790. Email: prmitha19@gmail.com 


\section{PENDAHULUAN}

Persaingan di dunia radio dirasakan semakin kuat dan ketat. Hal ini pun dirasakan oleh Radio OZ sebagai radio yang telah berdiri selama 44 tahun dan pernah mengalami era dimana radio dianggap media yang sangat penting karena dengan penyampaian informasi yang cepat. Radio juga sempat menjadi media yang menjadi trend atau lifestyle masyarakat terutama anak muda yang berkompetisi untuk menjadi $C l u b$ pendengar setia radio yang kemudian sekarang radio sendiri dirasakan semakin ditinggalkan dan teralih pada media baru.

Meskipun begitu, hal ini dapat diatasi apabila radio memiliki program ataupun strategi yang dapat menarik hati pendengarnya. Pendengar radio juga dikenal sebagai pendengar yang loyal terhadap radionya, berbeda dengan penonton televisi yang menyukai programnya dari pada perusahaan televisinya sendiri. Dengan begitu apabila radio dapat mengemas program-program yang disiarkan secara menarik dan dapat mengambil perhatian pendengarnya maka pendengar setia pun secara tidak langsung akan setia mendengarkan radio.

Radio OZ merupakan salah satu radio swasta besar di kota Bandung yang lahir dari sebuah ide kreatif anak muda pada tahun 1971. Sejak pertama kali mengudara, Radio OZ Bandung berkeinginan untuk memposisikan diri menjadi radio anak muda. Kenyataannya, Radio OZ kini melakukan perubahan untuk menjadi radio bagi dewasa muda juga dan menciptakan kesan yang friendly di benak pendengarnya. Namun kemasan program, content program, dan halhal lain yang terkait dengan manajemen masih mencerminkan Radio OZ sebagai radio anak muda

Sudah menjadi kewajiban bagi public relations Radio OZ untuk membuat suatu kegiatan atau inovasi baru agar dapat mempertahankan eksistensinya di benak masyarakat. Setelah mengetahui adanya perkembangan dari jumlah radio di Indonesia yang semakin bertambah di setiap tahunnya ditambah dengan data dari riset Nielsen Audiens Measurement Indonesia yang menyatakan bahwa Radio OZ memiliki posisi di bawah radio pesaingnya, Radio OZ kemudian memutuskan untuk melakukan Focus Group Discussion (FGD) untuk menjadi alat untuk mengumpulkan data. Dimana data ini dikumpulkan untuk menentukan inovasi atau kegiatan apa yang akan dilakukan Radio OZ selanjutnya untuk menghadapi permasalahan yang ada.

Menunjang transformasi segmentasi pendengar, Radio OZ sudah tidak terfokus pada pembuatan program baru saja melainkan mereka kini memanfaatkan digital marketing. Sedikitnya terdapat empat manfaat digital 
marketing dalam memaksimalkan suatu bisnis, diantaranya adalah menghemat biaya promosi, menjangkau pasar yang lebih luas, sebagai sarana untuk meningkatkan penjualan, dan menjadi sarana penghubung yang baik dengan konsumen (Tresnawati \& Prasetyo, 2018). Radio OZ kini tidak hanya dapat didengar melalui radio yang membutuhkan frekuensi namun dapat di streaming melalui berbagai aplikasi yang dapat dijangkau melalui koneksi internet. Media streaming yang disediakan Radio OZ diantaranya TuneIn untuk streaming radio berbentuk audio dan Zeemi TV untuk berbentuk video. Selain bisa mendengarkan radio secara mobile, Radio OZ juga memfasilitasi pendengar dengan akses media sosial yang variatif yaitu diantaranya Twitter, Facebook, Youtube, Instagram, Path, Periscope dan Line.

Harapan adanya kesan yang terbentuk di benak masyarakat yaitu menjadi radio yang dikenal friendly yang dapat dikonsumsi siapa saja yang berjiwa muda terutama khalayak dewasa muda, maka Radio OZ mengoptimalkan penggunaan social media untuk menjadi media pemasaran. Dari pernyataan Ibu Massayu Mayasari selaku bagian Social Media Marketing Radio OZ dapat dipahami bahwa Social Media yang paling cepat untuk mendapatkan respon secara langsung dari masyarakat ialah media sosial Twitter dan Instagram. Menurut survei yang dilakukan oleh TNS, sebuah lembaga riset dari Inggris, 59\% pengguna Instagram di Indonesia adalah 18-24 tahun dan diantaranya adalah perempuan (Beritagar.id). Kemunculan Instagram membuat masyarakat di Bandung cenderung lebih sering mencari informasi melalui aplikasi media sosial Instagram melalui handphone dan membuat perubahan sosial kepada penggunanya (Ayutiani \& Putri, 2018). Oleh karena itu Radio OZ memilih Instagram sebagai media interaksi dengan pendengar. Dalam media sosial Instagram, antara pendengar dengan Radio OZ dapat saling memberikan feedback secara langsung yaitu berupa comment, direct message, dan likes pada kolom yang disediakan. Masyarakat juga dapat sharing foto/e-poster Radio OZ ke pengguna Intsagram lainnya. Followers yang dimiliki oleh Radio OZ dalam media sosial Instagram yaitu mencapai 8050 followers yang menjadi salah satu media sosial baru bagi Radio OZ sendiri. Di lain hal, Instagram ternyata memiliki jumlah pengguna lebih banyak daripada Twitter. Jumlah pemilik akun aktif Instagram telah mencapai 300 juta yang telah melampaui Twitter yang memiliki 284 juta akun. Banyak bisnis yang telah berkembang melalui aplikasi Instagram. Instagram dijadikan sebagai media dalam mempromosikan maupun menjual produk (Butar-Butar \& Ali, 2018).

Dalam memahami situasi, Radio OZ mempertimbangkan perubahan yang dilakukan 
dengan memantau hasil riset AC Nielsen, permintaan klien, dan juga faktor lingkungan. Dengan keputusan perubahan tersebut Radio OZ memilih media sosial Instagram karena dianggap sebagai media yang dapat dengan mudah memberikan feedback dengan pendengar serta menjadi media sosial yang sedang marak digunakan. Tujuan Radio OZ menggunakan media sosial Instagram ini sendiri adalah untuk meraih pendengar baru dengan segmentasi usia dewasa muda serta memberikan informasi mengenai perusahaan.

Penggunaan media sosial Instagram, Radio OZ melakukan strategi yang berbeda dengan radio lainnya yaitu dengan membuat konten kreatif. Berita yang dikemas menjadi e-poster serta diberikan gimmick agar lebih menarik untuk dilihat. Selain itu dalam melaksanakan taktik, Radio OZ melakukan evaluasi yang kurang mendalam yaitu hanya dengan memantau peningkatan jumlah followers dan likes. Timeline yang ditentukan oleh Radio OZ dalam penggunaan media sosial ini sendiri masih belum memiliki jadwal teratur yaitu hanya menargetkan 3 foto yang diunggah dalam sehari. Sedangkan untuk biaya sendiri Radio OZ tidak memiliki budget yang disediakan untuk kegiatan aktivasi media sosial Instagram.

Saat ini peran internet bukan hanya sebagai sarana mencari informasi, tapi juga mempunyai potensi besar sebagai media pemasaran. Pemasaran dengan memanfaatkan media internet disebut internet marketing atau electronic marketing (e-marketing). Salah satu media atau aplikasi pendukung kegiatan emarketing yang sedang terus berkembang adalah media sosial Instagram, sebuah aplikasi yang memungkinkan pengguna untuk mengambil foto, menerapkan filter digital atau pemberian efek pada foto, dan membagikannya. Dengan media sosial yang tersedia bagi jutaan orang di seluruh dunia, perusahaan dapat berinteraksi dengan pelanggan dari berbagai negara dan sebaliknya, (Zulfikar, 2017).

Oleh karena itu, Radio OZ selalu update mengenai kegiatan, program dan juga informasi yang dibagikan kepada masyarakat baik dalam bentuk e-poster atau video berdurasi 15 detik yang diisi dengan caption tanpa batas karakter. Hal inilah yang kemudian membuat peneliti tertarik untuk memilih media sosial Instagram dibandingkan dengan media sosial lainnya yang dimiliki oleh Radio OZ karena di Instagram dapat memberikan caption dengan bebas, berbentuk visual, dan memiliki pengguna paling banyak di Indonesia dibandingkan dengan media sosial lainnya. Oleh karena itu, penulis ingin menggambarkan dan menjelaskan bagaimana strategi perencanaan media sosial dengan menggambarkan dan menjelaskan situasi, tujuan, target, strategi, taktik dan 
timeline dari Radio OZ dalam menggunakan media sosial.

Keberadaan media sosial kini terus merambah kehidupan manusia. Dalam perkembangannya media sosial bisa dimanfaatkan untuk beragam kepentingan, mulai menjalin pertemanan, kampanye program tertentu (pendidikan, sosial, agama, lingkungan, kesehatan, dan sebagainya), sampai promosi dan pemasaran produk atau jasa tertentu. Adanya kemajuan yang pesat dibidang teknologi informasi diimbangi dengan kemajuan teknologi transportasi dan manajemen logistik. Hal tersebut makin memudahkan terjadinya lalu lintas manusia sekaligus barang. Dua hal tersebut selayaknya menjadi peluang usaha yang harus dimanfaatkan. Dalam hal ini, bagaimana mendayagunakan media sosial seperti Facebook dan Twitter atau yang lainnya untuk memasarkan produk (Suryani, 2014).

\section{METODE PENELITIAN}

\section{Metodologi penelitian membahas}

konsep teroretik berbagai metode, kelebihan dan kekurangannya, sedangkan metode penelitian hanya mengemukakan secara teknis tentang metode-metode yang digunakannya dalam penelitian (Muhadjir, 2000). Adapun metode yang digunakan dalam penelitian ini adalah metode deskriptif. Metode deskriptif menitikberatkan pada observasi dan suasana ilmiah (natural setting) yang ada. Penelitian ini tidak mencari atau menjelaskan hubungan, tidak menguji hipotesis atau membuat prediksi. Pada penelitian deskriptif, peneliti ditempatkan sebagai pengamat agar dapat terjun langsung untuk mengumpulkan informasi, mengidentifikasi masalah, membuat perbandingan serta menentukan apa yang dilakukan untuk memperoleh data yang akurat. Penelitian deskriptif hanyalah memaparkan situasi atau peristiwa saja. Penelitian ini tidak mencari atau menjelaskan hubungan, tidak menguji hipotesis atau membuat prediksi Penelitian deskriptif dapat berupa kuantitatif, kualitatif, dan dapat pula kombinasi keduanya. Penelitian deskriptif kualitatif diuraikan dengan kata-kata menurut pendapat responden, apa adanya sesuai dengan pertanyaan penelitiannya, kemudian dianalisis pula dengan kata-kata apa yang melatarbelakangi responden berperilaku (Rakhmat, 2007).

Penelitian deskriptif dilakukan untuk berbagai macam tujuan, diantaranya: mengumpulkan informasi aktual secara rinci yang melukiskan gejala-gejala yang ada, mengidentifikasi masalah atau memeriksa kondisi dan praktek-praktek yang berlaku, membuat perbandingan atau evaluasi terhadap suatu program atau fenomena tertentu, menentukan apa yang dilakukan orang lain dalam menghadapi masalah yang sama dan belajar dari 
pengalaman mereka untuk menetapkan rencana dan keputusan pada waktu yang akan datang (Moleong, 2010). Adapun pengertian deskriptif menurut (Sugiyono, 2006) adalah metode yang berfungsi untuk mendeskripsikan atau memberi gambaran terhadap objek yang di teliti melalui data yang telah terkumpul sebagaimana adanya tanpa melakukan analisis dan membuat kesimpulan yang berlaku umum. Peneliti menggunakan metode deskriptif dikarenakan peneliti ingin menggambarkan berdasarkan fakta yang ada mengenai masalah yang terjadi dengan cara penyelesainnya dan berlandaskan pada konsep penggunaan media sosial. Peneliti juga langsung mewawancarai dan melihat realita yang ada secara langsung agar dapat menggambarkan kenyataan yang terjadi.

\section{HASIL DAN PEMBAHASAN}

Analisis situasi pemilihan media sosial sebagai upaya transformasi pendengar.Gantama F. Ganjar selaku General Manager Radio OZ Bandung menyatakan salah satu alasan Radio OZ memperluas segmentasi pendengarnya hingga dewasa muda karena adanya permintaan dari klien dan sponsor yang ingin membeli spot-spot iklan di Radio OZ dengan harapan pendengar Radio OZ dapat lebih luas. Andrie Kemir Maulana selaku Program Director Radio OZ juga memaparkan latar belakang hingga terciptanya perubahan pendengar Radio $\mathrm{OZ}$ yaitu untuk meningkatkan pendengar dan dapat mempertahankan eksistensinya di dunia penyiaran radio khususnya di kota Bandung. Posisi Radio OZ berdasarkan riset AC Nielsen apabila dilihat dari jumlah pendengar masih berada dibawah radio pesaingnya yaitu ARDAN FM, dimana pada wave 3 (Juli-September) tahun 2015 memiliki jumlah pendengar hingga 613.000 pendengar sedangkan Radio OZ memiliki 63.000 pendengar. Agar tercapai tujuan tersebut maka Radio OZ memberanikan diri untuk melakukan inovasi dengan melakukan transformasi pendengar lebih luas dan Radio OZ siap untuk bersaing dengan pesaing-pesaing dengan segmentasi yang sama seperti ARDAN, URBAN, I-RADIO, dan 99ERS. Menurut Harris, analis situasi idealnya dilakukan pada tiga bagian, yakni produknya, targetnya dan pada lingkunganya (Harris, 1991). Dalam konteks transformasi Radio OZ, produk yang dimaksud adalah strategi digital marketing untuk memperluas segmentasi publik.

Radio OZ menganalisa dan membahas latar belakang pada produk yang diluncurkan. Mulai dari deskripsi latar belakang, manfaat, ukuran, bentuk, harga, hingga saluran distribusi. Jika yang dipasarkan bukan produk baru, maka penjualan produk dan sejarah promosi juga harus disertakan. Oleh karena itu Radio OZ juga meluncurkan strategi pemasaran yang akan dilakukan. Dimana Radio OZ melakukan 
transformasi pada radionya yang tadinya target pendengar hanya untuk anak muda saja namun kini diperluas hingga dewasa muda dengan range umur 15-36 tahun. Adapun penentuan target market dilihat dari profil demografi dan psikografi. Namun demikian dari segi marketing public relations menyarankan untuk tidak hanya mencapai target pasar utama, tetapi juga khalayak konsumen sekunder, opinion leaders, dan audiens yang sudah ditargetkan. Pada aspek lingkungan Radio OZ perlu menekankan informasi tentang pangsa pasar dan penjelasan dari perubahan saham. persaingan langsung dan tidak langsung, kekuatan dan kelemahan dari merek bersaing, perbedaan geografis, dan deskripsi dari program promosi adalah bagian dari lingkungan pemasaran. Begitu juga ancaman terhadap produk atau kategori itu, karena keselamatan atau kemanjuran, mungkin meletakkannya pada risiko.

Tiga aspek utama dalam analisis situasi telah dilakukan oleh Radio OZ, yakni Pada aspek pertama adalah dalam penelitian ini yang diluncurkan bukan hanya produk baru saja, namun strategi pemasaran yang dilakukan. Dimana Radio OZ Bandung melakukan transformasi pada radionya yang tadinya target pendengar hanya untuk anak muda saja namun kini diperluas hingga dewasa muda dengan range umur 15-36 tahun. Kemudian aspek yang kedua adalah Radio OZ Bandung telah menentukan target pasar yang ingin dituju pada pemasaran ini yaitu pada umur 15-35 tahun dengan meraih segmentasi baru yaitu dewasa muda. Kemudian pada aspek yang ketiga yaitu lingkungan, Radio $\mathrm{OZ}$ telah mengetahui persaingan yang semakin kuat dimana jumlah radio yang bertambah di Indonesia setiap tahunnya kemudian interest masyarakat yang berkurang karena adanya gadget sehingga akhirnya mendorong Radio OZ untuk berani melakukan perubahan. Begitupun dalam memilih media sosial Instagram sebagai salah satu media pemasaran. Media sosial merupakan salah satu kegiatan dari digital marketing. Digital marketing adalah kegiatan marketing termasuk branding yang menggunakan berbagai media berbasis web seperti blog, website, e-mail, adwords, ataupun jejaring sosial (Sanjaya \& Tarigan, 2009).

Terdapat alasan yang dimiliki Radio OZ hingga memilih media sosial Instagram sebagai salah satu media pemasaran Radio OZ dalam memasarkan perubahan yang terjadi. Dari pernyataan Gantama F. Gandjar selaku General Manager Radio OZ dapat dipahami bahwa alasan Radio OZ Bandung memilih media sosial Instagram sebagai salah satu media untuk memasarkan perubahannya dikarenakan melihat situasi yang ada. Dimana situasi di sini dapat diketahui bahwa media sosial kini marak digunakan oleh masyarakat Indonesia, khususnya masyarakat yang termasuk dalam 
segmentasi Radio OZ Bandung yaitu pada usia 15-35 tahun. Instagram juga menjadi media sosial yang sedang booming setelah mengalahkan eksistensi dari media sosial Twitter.

Tujuan merupakan hal yang penting untuk ditentukan karena tanpa tujuan, strategi dan taktik yang dilakukan akan berjalan tanpa arah. Dalam menentukan tujuan, didasari oleh alasan dan latar belakang dilakukannya suatu kegiatan. Seperti dalam penelitian ini, tujuan Radio OZ Bandung dalam menggunakan media sosial Instagram tentu ditetapkan untuk mendukung misi dari perusahaan sendiri. Tujuan yang benar harus dapat mengambarkan program apa yang akan dilakukan. Suatu program atau strategi akan dievaluasi keberhasilannya dengan membandingkan dengan tujuan yang telah ditetapkan. Tujuan biasanya ditetapkan untuk mengkomunikasikan informasi, meningkatkan awareness, dan memengaruhi untuk membeli atau mengkonsumsi produk (Harris, 1991).

Tujuan yang ditetapkan oleh tujuan utama dalam penggunaan media social Instagram sebagai salah satu strategi digital marketing yang digunakan oleh Radio OZ yaitu untuk meraih pendengar baru yang bersegmentasi dewasa muda dan juga memberikan informasi secara tersirat kepada pendengar adanya perubahan yang dilakukan Radio OZ yang kini tidak bersegmentasi anak muda lagi namun mencakup dewasa muda juga. Sehingga dapat diketahui tujuan yang ditetapkan sudah sesuai dengan definisi diatas yang dimana tujuan ini lebih mengarah pada mengkomunikasikan informasi secara tersirat mengenai perubahan yang dialami, meningkatkan awareness adanya perubahan Radio OZ Bandung yang dapat dilihat dari logo dan baru, serta memengaruhi umur dewasa muda untuk mulai mendengarkan Radio OZ Bandung.

Luttrell menyatakan bahwa pada media sosial photo sharing seperti Instagram, Flickr, Facebook Photo Gallery, Company Blog, Google+ Photo Album maupun Pinterest, tujuan dapat dicapai dengan:

"Mendorong karyawan untuk share foto yang menarik mengenai public relations/ yang berhubungan dengan marketing terkait baik dari social marketing maupun kegiatan perusahaan, mengambil gambar di acara-acara yang disponsori perusahaan yang relevan seperti pameran dagang, peluncuran produk atau kejadian masyarakat, dan mengundang influencer untuk mengambil foto dan berbagi foto sehingga followers influencer tersebut dapat melihat foto tersebut." (Luttrell, 2015)

Radio OZ telah melakukan beberapa cara untuk mencapai tujuan dari media sosial jenis photo sharing yaitu diantaranya karyawan yang mengunggah tentang perusahaan di akun media sosial mereka, mengambil gambar di acara yang disponsori perusahaan kemudian mengunggahnya, dan mengundang influencers berfoto kemudian mengunggahnya. Tujuan 
merupakan dasar dari setiap strategi digital. Tujuan digital strategi biasanya meliputi meningkatkan awareness, membangun masyarakat atau mengedukasi masyarakat, meningkatkan reputasi, dan membuat perbincangan. Apabila dikaitkan dengan tujuan Radio OZ menggunakan media sosial Instagram untuk transformasi yang dilakukan yaitu ingin meningkatkan jumlah pendengar serta memberikan informasi secara tersirat kepada pendengar adanya perubahan yang dilakukan Radio OZ kini peneliti dapat menyimpulkan bahwa tujuan yang ditetapkan Radio OZ sesuai dengan konsep diatas terutama tujuan ini tidak lain adalah untuk meningkatkan reputasi dengan ingin meningkatkan jumlah pendengar dan membangun masyarakat akan pengetahuan mengenai segala kegiatan perusahaan termasuk perubahan yang dilakukan Radio OZ (Red Ant, 2013).

Penentuan target sasaran merupakan hal yang diutamakan untuk membangun strategi dan taktik yang akan dilakukan. Dalam menentukan target sasaran dalam media sosial Instagram, Radio OZ melakukan hal yang sama sesuai dengan bagaimana Radio OZ menentukan target sasaran yang baru pada keputusan transformasi. Dalam tahap penentuan target sasaran dapat melihat apakah perusahaan memperhatikan area yang spesifik atau menargetkan publik dari keseluruhan, upaya media sosial harus ditargetkan secara langsung kepada publik yang lebih spesifik. Dalam menentukan publik, perusahaan harus benar-benar memahami demografi publiknya yang diinginkan.

Menurut Harris, penentuan target markets ditentukan dari profile demografi dan psikografi (Harris, 1991). Oleh karena itu disarankan untuk tidak hanya mencapai target pasar utama, tetapi juga khalayak konsumen sekunder, opinion leaders, dan audiens yang sudah ditargetkan. Sedangkan di lain hal, Radio OZ pun berharap melalui media sosial Instagram yang sifatnya luas dan tidak dibataskan oleh waktu, Radio OZ juga dapat di dengar oleh masyarakat luas yang tidak hanya masyarakat Bandung saja melainkan luar kota bahkan luar negeri karena dengan adanya digital Radio OZ dapat di streaming melalui website Radio OZ. Hasil wawancara dengan Detta Rahmawan selaku pakar media mengatakan bahwa yang dilakukan Radio OZ dengan mengoptimalkan media sosial Instagram sebagai salah satu media sosialnya pun dianggap baik karena pengguna media sosial Instagram memang memiliki karakteristik masyarakat anak muda hingga dewasa. Instagram juga memiliki pengguna yang paling banyak di antara media sosial lainnya.

Penggunaan media sosial instagram sebagai salah satu strategi dari digital marketing dilakukan Radio OZ memiliki tujuan, salah 
satunya adalah mengkomunikasikan perubahan yang dilakukan oleh Radio OZ yaitu dengan memperluas segmentasi pasar hingga meraih umur dewasa muda. Penggunaan media sosial Instagram tentu tidak hanya dilakukan oleh Radio OZ saja. Radio sejenis nya tepatnya di Kota Bandung seperti ARDAN FM, Play 99ERS, I-Radio, dan lainnya memiliki media sosial yang sama. Dengan begitu, untuk mengoptimalkan media sosial Instagram yang Radio OZ miliki harus dilakukan suatu strategi agar dapat menarik perhatian pendengar dan meningkatkan jumlah followers serta mempertahankan followers untuk tidak mengunfollow.

Strategi yang diterapkan pada media sosial Instagram yang membedakan dengan radio sejenisnya adalah informasi yang diberikan tidak hanya mengenai perusahaan dan iklan melainkan memasukkan e-poster mengenai berita terbaru dan menciptakan gimmick pada e-poster tersebut agar terlihat bercerita dan berseni. Cara Radio OZ membuat konten yang menarik tidak lain adalah dengan mencari berita yang orang-orang sukai dan terbaru sehingga meningkatkan rasa penasaran dari followers. Radio OZ juga sering membuat e-poster yang lucu dan unik hingga design yang artsy untuk meningkatkan keinginan followers untuk comment di media sosial Instagram.

Ketika membuat konten, Radio OZ memperhatikan pemilihan tone warna dengan warna calm/glamour, pemilihan font, dan design yang maksimal. Dampak yang dirasakan dengan adanya media sosial Instagram sebagai media pemasaran yaitu pendengar dewasa muda mulai menyadari dengan adanya perubahan ini dan followers yang bertambah banyak dari usia dewasa muda. Dengan adanya media sosial Instagram juga mempermudah penyampaian perubahan karena apabila melalui on-air saja tidak akan maksimal. Berdasarkan hasil wawancara dengan Ayu Lakhsmi Daeng Ugi selaku praktisisocialmedia strategymengatakan bahwa strategi yang baik pada media sosial Instagram adalah adanya konten kreatif. Konten kreatif adalah konten yang dibuat oleh suatu brand yang tidak berkaitan dengan perusahaan melainkan mengenai apa yang sedang ramai dibincangkan oleh masyarakat atau sedang ngetrend.

Apabila dikaitkan dengan pernyataan narasumber di atas dapat dipahami bahwa apa yang telah dilakukan Radio OZ sudah sesuai dan dapat dipertahankan sehingga konten kreatif terus berkembang dan tidak monoton. Sedangkan apabila dilihat dari apa yang dikatakan Detta Rahmawan selaku pakar media bahwa pada media sosial baik bagi perusahaan untuk berusaha bagaimana caranya masyarakat itu bukan hanya sekedar menjadi pembeli namun menjadi brand advocate. Brand advocate di sini 
dimana individu tersebut memasarkan sebuah brand ke orang-orang lain sehingga pesan pun tidak berhenti di situ dan terus menyebar.

Radio OZ kurang memanfaatkan influencers untuk ikut serta me-repost postingan dari Instagram Radio OZ. Contohnya apabila ada bintang tamu artis, Radio OZ kurang memanfaatkan artis tersebut untuk ikut serta mengkomunikasikan pesan di Instagram Radio OZ melalui akun Instagram artis tersebut. Menurut Luttrell terdapat tiga fitur utama yang menarik pengguna untuk menggunakan media sosial Instagram yaitu: personalization memberikan penawaran kepada followers Instagram kesempatan untuk mendapatkan sesuatu hal yang berbeda dari produk perusahaan (Luttrell, 2015). Lifestyle perusahaan bertujuan untuk mempromosikan merek sebagai bagian dari pilihan gaya hidup dan salah satu yang harus dinikmati dengan teman-teman. Exclusivity pengguna Instagram menjadi terbiasa melihat foto-foto eksklusif, termasuk melihat foto ataupun video behindthe-scenes di perusahaan favorit mereka .

Dari penggalan 3 (tiga) fitur utama dari media sosial Instagram, Radio OZ telah memanfaatkan media sosial Instagram dan memenuhi ketiga fitur utama tersebut. Dimana Radio OZ memberikan hal yang berbeda dengan radio sejenisnya sehingga terciptanya offering yang berbeda dengan media sosial
Instagram lainnya, kemudian juga Radio $\mathrm{OZ}$ yang memberikan foto dan video berbentuk behind-the-scenes mulai dari foto/video karyawan yang sedang mempersiapkan suatu event, hingga announcers yang direkam offthe-record siaran on-air sehingga hal ini hanya didapat followers pada media sosial Instagram. Dengan menentukan tema warna pada Instagram kemudian juga menentukan konten yang akan diunggah dipertimbangkan agar kesan dewasa akan timbul tentu akan membuat masyarakat menyadari akan perubahan dan mulai memiliki kesan dewasa terhadap Radio OZ.

Perusahaan memanfaatkan saluran seperti Instagram untuk menjalin hubungan dengan pengguna online, investor, stakeholder, konsumen, dan prospek. Media sosial photosharing seperti Instagram memperbolehkan penggunanya untuk memberikan kecintaan mereka secara langsung terhadap perusahaan yang mereka sukai. Semakin banyak yang dibagikan suatu perusahaan kepada konsumennya, semakin banyak juga hal yang dibagikan konsumen kepada followersnya. Instagram memperbolehkan perusahaan untuk membuat komunitas, membagikan foto, membangun kepercayaan, dan meningkatkan keaslian dengan konsumen di media sosial Instagram (Luttrell, 2015).

Dalam melaksanakan strategi yang tentu terdapat taktik-taktik yang diterapkan pada 
media sosial Instagram untuk mendukung pemasaran transformasi yang dilakukan serta mempertahankan followers media sosial Instagram Radio OZ. Taktik khusus yang dilakukan Radio OZ dalam memasarkan perubahan adalah dengan menggunakan logo sebagai ribbon dalam setiap foto yang diposting serta mencantumkan baru "Your Friendly Station" pada kolom caption. Sedangkan, taktik yang dilakukan Radio OZ utnuk mengoptimalkan media sosial Instagram adalah dengan mengutamakan fast respond dan bahasa yang dipilih untuk membalas comment yang ramah dan friendly. Sesuai dengan transformasi yang dilakukan, cara Radio OZ untuk merespon dengan cara yang friendly mendukung tagline baru Radio OZ Bandung yaitu "Your Friendly Station". Taktik yang dilakukan Radio OZ Bandung untuk mempertahankan dan meningkatkan followers yaitu dengan mengadakan quiz baik itu photo competition maupun video competition.

Akun instagram suatu perusahaan dapat melayani beberapa tujuan, tapi selain itu, media sosial Instagram harus membuat pengguna merasa disertakan dan bagian dari perusahaan. Beberapa taktik yang perlu dipertimbangkan ketika merencanakan menggunakan Instagram adalah sebagai berikut: produk baru, foto produk baru, bagikan screenshot-nya, bahkan share foto seseorang yang menggunakan produk baru tersebut di Instagram. Foto Instagram harus sederhana dan dapat mempromosikan dengan menggunakan efek yang diinginkan melalui penggunaan filter foto yang tersedia. Budaya perusahaan dan karyawan, gunakan media sosial Instagram untuk memanusiakan merek perusahaan. Soroti internal perusahaan yang berkaitan dengan budaya perusahaan. Berikan followers wawasan sehari-hari mengenai aktivitas behind-the-scene. Buat foto yang menyenangkan dengan menggunakan gambar yang lebih santai/tidak formal. Trending topics dan event, selain posting foto dari event perusahaan, gambarkan bahwa perusahaan terlibat dan memberikan informasi mengenai event yang berkaitan dengan followers. Posting foto Instagram mengenai berita, fun facts, dan trending topics yang followers ketahui dan kemudian ikut sertakan followers melalui topik tersebut. Photo contest, pengguna Instagram menyukai aplikasi karena mereka dapat membuat foto yang menyenangkan. Gunakan kegemaran ini untuk keuntungan perusahaan. Mengembangkan dan meluncurkan photo contest di mana followers dapat mengirimkan foto dan dapat diakui oleh perusahaan yang mereka sukai. Photo contest ini membantu meningkatkan jumlah followers, membuat loyalitas terhadap perusahaan, dan juga menyediakan platform bagi perusahaan untuk terlibat dengan komunitas yang ada pada 
pengguna media sosial Instagram (Luttrell, 2015).

Selain itu, tidak jarang juga Radio OZ memposting foto dari karyawan dan kegiatan internal pada media sosial Instagram sehingga followers dapat mengetahui bagaimana budaya perusahaan Radio OZ. Kemudian untuk konten yang di posting pada media sosial Instagram, Radio OZ juga membuat strategi yang tidak dimiliki oleh radio sejenisnya dimana Radio OZ mem-posting berita yang sedang hits dan ramai dibincangkan oleh anak muda dan dewasa muda dan juga memberikan gimmick tersendiri pada e-poster yang diupload yang menimbulkan efek lucu sehingga followers pun bertahan untuk tetap mem-follow media sosial Instagram Radio OZ. Pada konsep taktik di atas pun menyebutkan adanya photo contest, Radio OZ sendiri sering mengadakan photo contest untuk mendapatkan hadiah baik hadiah yang hanya berbentuk merchandise Radio OZ hingga hadiah tiket konser.

Dapat diketahui Radio OZ mengatur media sosial Instagram dengan membuat konten yang tidak membosankan dengan menyelipkan video berdurasi 15 detik, kemudian berusaha untuk selalu update setiap harinya dan memberikan berita terbaru dan fresh, dan juga melakukan media monitoring. Melalui comment di dalam media sosial Instagram, Radio OZ terbiasa berkomunikasi dengan para pendengar. Semua situs media sosial berbagi video, masingmasing memiliki aturan sendiri, kendala waktu, dan penggunaan. Ketika menggunakan platform ini untuk syuting video, ada beberapa panduan yang dapat digunakan, diantaranya: kenali audiens dan platform-nya, mengetahui harus seberapa durasi video dan menempatkan video tersebut pada media sosial yang sesuai. Mengetahui durasi video berarti diperlukannya mengetahui audiens, platform yang paling baik digunakan dari konten yang ingin dipromosi, dan media sosial yang sekiranya memiliki impact yang paling besar. Tujuan dan storyboard, memahami tujuan dan membuat ide storyboard merupakan step pertama untuk membuat video perusahaan. Menentukan tujuan membantu untuk menyampaikan pesan yang tepat kepada audiens. Style dan tone, video dapat bertema lucu, cheerful, profesional, serius, dll. Tema yang dipilih harus disesuaikan dengan style dan tone pada video. Beberapa tips dalam menentukannya yaitu: tone: upbeat, riang, serius, atau tenang. Dialogue: style “talking head" interview atau pembicaraan yang bebas. Production quality: in-house studio atau di lokasi tertentu, video quality: simple online, video made-it-myself, atau produksi profesional dengan budget besar. Penulisan naskah, setelah tujuan dan tone sudah ditetapkan, kemudian selanjutnya adalah penulisan naskah. Apabila video berbentuk interview seperti pada Youtube, 
menulis list pertanyaan sangat perlu disiapkan. Angle dan shot, ingat bahwa semua video harus berhubungan, dapatdidiskusikan, dan dibagikan. Saat syuting video, perlu dipertimbangkan angle/sudut terbaik dan perspektif untuk setiap urutan. Image, sound dan lighting, elemen ini mendukung tone, dialog, dan efektivitas dari pesan yang disampaikan. Saat membuat storyboard, pikirkan tentang tipe shots, musik dan backsounds yang dapat digunakan. Editing hingga produksi akhir, pada media Youtube, editing dilakukan di iMovie, Camtasia, dan Windows Movie Maker. Share, setelah video telah siap untuk diproduksi, saatnya untuk mempublikasikan atau melakukan upload video yang telah dibuat pada media sosial. Hal ini dapat dibarengi dengan menggunakan tag, hashtag, dan caption yang mendukung (Luttrell, 2015).

Evaluasi yang dilakukan Radio OZ dalam penggunaan media sosial Instagram masih menggunakan cara manual yang dievaluasi 3 (tiga) bulan sekali. Pada 3 (tiga) bulan terakhir, kenaikan followers mencapai angka 4000 followers hingga sekarang memiliki 7904 followers. Namun untuk rata-rata likes masih belum mengalami kenaikan, rata-rata hanya sekitar 50-80 likes/foto. Dalam hal pengukuran, mampu menggambarkan hasil dan memahami matriks dengan benar merupakan hal yang penting pada semua platform media sosial karena analisis dapat menentukan strategi pada media sosial. Statigram merupakan alat khusus yang dikembangkan untuk pengguna Instagram, memungkinkan suatu brand untuk mengukur upaya mereka melalui matriks. Dengan Statigram, perusahaan dapat mengelola baik mengelola komentar maupun masyarakat secara bersamaan, dan juga menganalisis kegiatan perusahaan dalam Instagram.

Di lain hal, Ayu Lakhsmi Daeng Ugi selaku praktisi Social Media Strategy menyatakan berbicara taktik untuk mengevaluasi media sosial yang baik adalah dengan menggunakan analytic tools. Apabila evaluasi hanya berbentuk manual itu hanya diketahui permukaannya saja. Apabila menggunakan analytic tools, kita dapat mengetahui pertumbuhan followers dan likes, interaksi, hingga kata-kata apa yang disukai masyarakat yang ditulis pada kolom caption sehingga hasil dari evaluasi yang dilakukan benar-benar dapat menjadi masukan pada perusahaan untuk yang akan datang. Beliau juga memberikan masukan analytic tools yang dapat digunakan untuk mengevaluasi, di antaranya ada letter.com dan iconosquare. Dengan begitu alangkah lebih baik apabila Radio OZ mulai untuk menggunakan analytic tools seperti Statigram, letter.com, iconosquare, maupun aplikasi lainnya untuk menjadi alat pengukuran dan dapat menjadi bahan evaluasi atas strategi media sosial Instagram yang telah 
dilaksanakan.

Menjalankan digital marketing dalam penggunaan media sosial Instagram tentu Radio OZ memberikan informasi baik itu berupa foto, e-poster, maupun video melalui fitur upload foto yang disediakan. Dengan begitu, Radio OZ tentu memiliki jadwal tertentu untuk mengunggah foto agar followers dalam media sosial Instagram tidak ketinggalan informasi mengenai Radio OZ Bandung dan dapat terus mempertahankan kesetiaanfollowers untuk tidak meng-unfollow Instagram Radio OZ. Semakin direncanakan, strategi digital semakin mudah untuk mengaktualisasikan, dan memungkinkan lebih banyak waktu untuk berpikir tentang keterlibatan. Dan sangat memungkinkan untuk membangun sebuah timeline keterlibatan yang memungkinkan pesan di saluran untuk digunakan atau tidak digunakan yang disesuaikan dengan apa yang diperlukan. Red Ant menganjurkan untuk menggunakan Activity Calendar untuk mempermudah timeline yang dibuat pada media sosial (Red Ant, 2013).

Radio OZ menentukan jangka waktu dalam mengunggah foto minimal 3-5 foto dalam sehari sesuai dengan kebutuhan dan adanya kegiatan yang terjadi pada hari tersebut. Sedangkan jangka waktu dari pembuatan e-poster hingga jadwal pengunggahan tidak tentu. Pembuatan e-poster dibuat sekitar 2-4 jam dan langsung diunggah melalui media sosial instagram. Pada buku yang sama, Luttrell mengatakan dalam menggunakan media sosial waktu pelaksanaan perlu diperhatikan (Luttrell, 2015). Dimana dapat dipahami dalam menggunakan media sosial sebagai strategi, waktu yang dihabiskan perlu diperhatikan. Mulai dari mempertimbangkan berapa jam per hari, minggu, dan bulan untuk membuat foto, posting foto, dan mengelola gambar bagi perusahaan.

Dalam konsep tersebut disebutkan bahwa dalam menggunakan media sosial sebagai strategi, waktu yang dihabiskan perlu diperhatikan. Mulai dari mempertimbangkan berapa jam per hari, minggu, dan bulan untuk membuat foto, posting foto, dan mengelola gambar bagi perusahaan. Sedangkan Radio OZ hanya menentukan jumlah foto yang diunggah dalam sehari minimal 3 (tiga) foto. Adapun untuk jadwal pengunggahan, Radio OZ hanya memberikan jadwal pada iklan berbayar yaitu pada jam primetime, sedangkan foto lain yang berkaitan dengan program, berita, dan kegiatan perusahaan diunggah dalam waktu yang tidak dijadwalkan.

Menurut Ayu Lakhsmi Daeng Ugi praktisi social media strategy mengatakan bahwa timeline sangat dibutuhkan dalam penggunaan media sosial Instagram. Beliau juga mengatakan bahwa waktu mengunggah foto pada saat primetime sangat berpengaruh untuk interaksi (likes dan comment) yang tinggi. Terutama pada 
jam 7-12 malam pada saat dimana masyarakat sedang beristirahat dan bersiap untuk tidur. Hal ini didukung oleh adanya hasil dari analytic tools untuk media sosial yaitu khususnya untuk Instagram yaitu iconosquare dan juga latergramme yang menunjukkan bahwa waktu untuk mengunggah foto untuk media sosial Instagram lebih baik diunggah mulai pukul 7 malam hingga jam 12 malam. Apabila dilihat dari hasil penelitian di lapangan, Radio OZ hanya mengunggah iklan pada waktu primetime dan mengunggah konten lainnya secara tidak terjadwal pada jam yang lain. Sehingga apabila Radio OZ dapat memanfaatkan waktu primetime untuk mempromosikan radionya juga dengan mengunggah konten program, berita, maupun kegiatan internal akan lebih baik lagi dan lebih menarik perhatian followers juga untuk melihat akun Radio OZ.

Keberhasilan media baru membuat penggunaan media ini sangatlah penting saat ini karena kemudahannya dalamberkomunikasi dan pencarian informasi. Menurut Liliweri, media baru mengubah makna jarak geografis, dan juga memungkinkan terjadinya pertambahan volume informasi secara besar-besaran. Selain itu, media baru juga memungkinkan terjadinya bentuk komunikasi yang sebelumnya terpisah dan tumpang tindih menjadi komunikasi interkoneksi (Andiny, Nurhayati, \& Rahmasari, 2018). Media baru memasuki fase yang disebut dengan web 2.0 yang membuat semuanya menjadi lebih interaktif. Sebagai salah satu bentuk media komunikasi, Internet memiliki peran yang penting, yaitu sebagai alat untuk yang digunakan komunikator pesan untuk mengirimkan pesan kepada komunikan pesan. Salah satu media baru saat ini adalah media sosial.

Media sosial merupakan sarana interaksi bagi para pengguna melalui "sharing” informasi dan ide-ide; interaksi dilakukan menggunakan jaringan Internet yang diwadahi oleh suatu komunitas virtual. Dilihat dari perkembangan hubungan individu dengan perangkat media, media sosial dapat didefinisikan sebagai kumpulan perangkat dengan media Internet yang memungkinkan seseorang untuk berkomunikasi, berkumpul, dan berinteraksi dengan pengguna lainnya. Pengoperasian media biasanya mengacu pada penggunaan asas $4 \mathrm{C}$, yaitu context, communication, collaboration, dan connection. Context mengacu pada cara atau bentuk dalam menyampaikan suatu pesan kepada khalayak. Communication mengacu pada praktek penyampaian dan pembagian, juga proses mendengarkan, merespon, dan mengembangkan pesan kepada khalayak. Kemudian, collaboration mengacu pada kerjasama yang terjadi antara pemberi dan penerima pesan sehingga pesan yang disampaikan menjadi lebih efektif dan 
efisien. Terakhir, connection mengacu pada hubungan yang terjadi antara pemberi dan penerima pesan, keduanya berperan penting dalam menyampaikan pesan kepada khalayak dikarenakan setiap poin $4 \mathrm{C}$ tersebut memiliki peran dalam memberikan informasi yang baik dan benar. Media sosial dapat membuat pengguna tidak hanya menjadi penerima informasi, tapi juga menjadi pemberi informasi kepada pengguna lainnya (Andiny et al., 2018).

\section{SIMPULAN}

Perkembangan teknologi memberikan nilai lebih bagi bisnis penyiaran seperti Radio OZ, dimana mereka dapat mengelola teknologi komunikasi sebagai media informasi, komunikasi dan interaksi dengan pendengar. Perkembangan digital marketing dalam wujud media sosial memberikan kemudahan pagi pengelola penyiaran untuk mengkomunikasikan transformasi kepada pendengarnya. Namun demikian tetap harus memperhatikan langkah-langkah pemanfaatan media sosial di antaranya pemahaman situasi dengan mengedepankan penelitian sebagai radar akan kebutuhan pendengar. Langkah selanjutnya adalah menentukan tujuan pada tahap ini diperlukan komitmen dan konsistensi, dikarenakan hal ini berpengaruh pada penyusunan program. Pada bisnis penyiaran seperti Radio OZ pemetaan audience sangat diperlukan, ini merupakan langkah selanjutnya dari pemanfaatkan menggunakan media sosial sebagai media informasi. Dimana Radio OZ harus spesifik siapa yang akan menjadi target siaran mereka, disarankan menggunakan key opinion leader untuk merangkul pendengar. Tahapan selanjutnya yang harus diperhatikan sebelum menggunakan media sosial adalah pemilihan strategi dan taktik yang tepat dan cermat. Pesan kunci yang dirancang harus sesuai dengan target pasar, dan tidak kalah penting adalah pemilihan taktik pada media sosial harus mampu memengaruhi target pasar dengan menciptakan ruang interaksi dalam media sosial, sehingga akan berdampak pada impact yang powerful. Langkah terakhir adalah dengan merencanakan waktu penggunaan media sosial, apakah per minggu, bulan atau pun tahun. Semakin direncanakan strategi digital dengan memanfaatkan media sosial semakin mudah untuk mengaktualisasikan, dan memungkinkan lebih banyak waktu untuk memengaruhi pendengar.

\section{DAFTAR PUSTAKA}

Andiny, N. D., Nurhayati, I. K., \& Rahmasari, G. (2018). Efektivitas akun komunitas instagram@1000_guru_bdg dalam pemenuhan kebutuhan informasi followers. PRofesi Humas, 3(1), 81-101.

Ayutiani, D. N., \& Berlian Primadani Satria Putri. (2018). Penggunaan Akun Instagram sebagai Media Informasi Wisata Kuliner. 
PRofesi Humas, 3(1), 35-59.

Butar-Butar, C. R., \& Ali, D. S. F. (2018). Strategi personal branding selebgram non selebriti. PRofesi Humas, 2(2), 86-101.

Harris, L. T. (1991). The marketer's guide to public relations: how today's top companies are using the new pr to gain a competitive edge. United States Of America: John Wiley and Sons, Inc.

Luttrell, R. (2015). Social media:how to engage, share and connect. United States of America: Rowman dan Littlefield.

Moleong, J. L. (2010). Metodologi penelitian kualitatif. Bandung: Remaja Rosdakarya.

Muhadjir, N. (2000). Metodologi penelitian kualitatif. Yogyakarta: Rake Sarasin.

Rakhmat, J. (2007). Metode penelitian komunikasi: dilengkapi dengan contoh analistik statistik. Bandung: Remaja Rosdakarya.

Red Ant. (2013, September). Planning and
Managing a Digital Strategy. https://doi. org/10.2337/dc06-2192.

Sanjaya, R., \& Tarigan, J. (2009). Creative digital marketing. Jakarta: Elex Media Komputindo.

Sugiyono. (2006). Metode penelitian kuantitatif, kualitatif dan $r \& d$. Bandung: Alfabeta.

Suryani, I. (2014). Pemanfaatan media sosial sebagai media pemanfaatan produk dan potensi indonesia dalam upaya mendukung asean community 2015. Jurnal Komunikasi, 8(2), 123-138. Retrieved from https://doi. org/1907-898X

Tresnawati, Y., \& Prasetyo, K. (2018). Pemetaan Konten Promosi Digital Bisnis Kuliner kika's Catering di Media Sosial. PRofesi Humas, 3(1), 102-119.

Zulfikar, A. (2017). Pengaruh social media marketing terhadap brand trust pada followers instagram dompet dhuafa cabang yogyakarta. Jurnal Manajemen Dan Administrasi Islam, 1(2), 279-294. 